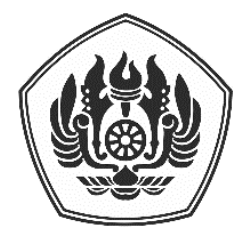

\author{
Padjadjaran Journal of International Law \\ ISSN: 2549-2152, EISSN: 2549-1296 \\ Volume 5, Number 1, January 2021
}

\title{
Establishing the Status of Responsibility to Protect (R2P) as Customary International Law and Its Role in Preventing Mass Atrocities
}

\author{
Sigar Aji Poerana, ${ }^{*}$ Irawati Handayani**
}

\begin{abstract}
Responsibility to Protect (R2P) was unanimously adopted and is articulated in paragraphs 138 and 139 of General Assembly Resolution A/Res/60/1. On the one hand, R2P has presumed a new name for humanitarian intervention that is still debatable in international law. On the other hand, R2P attempts to connect State's sovereignty and responsibility to protect human rights. $R 2 P$ recognizes State's sovereignty while bestowing States the primary responsibility to protect human rights and allowing the international community to intervene if States fail to fulfill their obligation. Considering the original idea of R2P is to protect human rights, the essential issue that should be addressed is the position of R2P as a source of international law. Suppose States should implement the R2P without a prior commitment to a treaty, which sources of international law that can underlie the legal basis for R2P? This article argues that R2P can fulfill the criteria of customary international law based on the notion of 'Grotian moment,' which 'compensates' R2P from the traditional burden of state practice and opinio juris since R2P is a paradigmshifting development in which new rules and doctrines of custom emerge with unusual rapidity and acceptance. Further, this article also highlights the importance of responsibility to prevent, which is one of the pillars of R2P, and argues that commitment to prevent is the "heart" of R2P. It is argued that such responsibility is vital in saving States from avoidable conflicts and from the trouble in responding to mass atrocities and rebuilding the affected population.
\end{abstract}

Keywords: Customary International Law, Grotian Moment, Responsibility to Protect, Responsibility to Prevent, Sources of International Law

\section{Menetapkan Responsibility to Protect (R2P) sebagai Hukum Kebiasaan Internasional dan Perannya dalam Mencegah Krisis Kemanusiaan}

\begin{abstract}
ABSTRAK
Responsibility to Protect (R2P) diadopsi dengan suara bulat dan dicantumkan dalam paragraf 138 dan 139 Resolusi Majelis Umum A/Res/60/1. Di satu sisi, R2P dianggap sebagai nama baru untuk intervensi kemanusiaan yang masih diperdebatkan dalam hukum internasional. Di sisi lain, R2P berupaya untuk menjembatani kedaulatan negara dan tanggung jawab untuk melindungi Hak Asasi Manusia (HAM). R2P tetap mengakui kedaulatan negara dan memberikan tanggung jawab utama kepada negara untuk melindungi HAM, namun mengizinkan masyarakat internasional untuk mengintervensi jika negara gagal memenuhi kewajibannya. Mengingat ide awal R2P adalah untuk melindungi HAM, maka isu penting yang

PADJADJARAN JOURNAL OF INTERNATIONAL LAW Volume 5 Issue 1 Year 2021 [ISSN 2549-2152] [e-ISSN 2549-1296] Researcher at Indonesian Center for International Law (ICIL), Jalan Imam Bonjol No. 21, Bandung, Indonesia, sigar.poerana@gmail.com.

** Lecturer at International Law Department Faculty of Law Universitas Padjadjaran and Researcher at Indonesian Center for International Law (ICIL), Jalan Imam Bonjol No. 21, Bandung, Indonesia, irawati@unpad.ac.id.
\end{abstract}


harus ditelaah adalah posisi R2P sebagai sumber hukum internasional. Misalnya, negara harus mengimplementasikan R2P tanpa komitmen terlebih dahulu terhadap suatu perjanjian internasional, sumber hukum internasional manakah yang dapat mendasari pelaksanaan R2P? Artikel ini berpendapat bahwa R2P dapat memenuhi kriteria hukum kebiasaan internasional berdasarkan konsep 'Grotian moment', yang 'mengkompensasi' R2P dari beban tradisional state practice dan opinio juris karena R2P merupakan perkembangan yang mengubah paradigma yang mengakibatkan aturan baru dan doktrin kebiasaan muncul dengan laju dan penerimaan yang luar biasa. Lebih lanjut, artikel ini juga menyoroti pentingnya tanggung jawab untuk mencegah, yang merupakan salah satu pilar dari R2P, dan berpendapat bahwa komitmen untuk mencegah adalah esensi dari R2P. Tanggung jawab untuk mencegah sangat penting dalam menjauhkan negara dari konflik yang dapat dihindari dan dari kesulitan dalam merespon krisis kemanusiaan dan membangun kembali penduduk yang terkena dampaknya.

Kata Kunci: Grotian Moment, Hukum Kebiasaan Internasional, Tanggung Jawab untuk Melindungi, Tanggung Jawab untuk Mencegah, Sumber Hukum Internasional

\section{A. INTRODUCTION}

Responsibility to Protect (R2P), in its formal introduction at the 2005 World Summit, has gained commitment from all members of the United Nations to implement R2P, and scholars have been ecstatic to study R2P as a human rights protection mechanism. Its narrative to shift sovereignty from a statecentric approach to a human-right-centric approach $^{1}$ gains the international community's confidence for adequate human rights protection.

From the outset, sovereignty limits foreign States to not intervene in other State's domestic affairs. However, states can perpetrate or omit to prevent or stop human rights violations within their border, for example, in Kosovo and Libya's situation. Subsequently, the 1997 - 2006 United Nations Secretary-General Kofi Annan reminded us that "The Charter protects the sovereignty of peoples. It was never meant as a license for governments to trample on human rights and human dignity". ${ }^{2}$
Annan reminded us, sovereignty to rule comes with a responsibility to protect. Once popularized as the 'right to rule,' sovereignty now should also be seen as a responsibility ${ }^{3}$ since sovereignty is often misused to prevent foreign states from intervening for humanitarian purposes. However, the international community realized that human rights protection is not only a concern of domestic affairs but also humankind as a whole. ${ }^{4}$ Thus, intervention became, to some extent, justified.

Intervention in Kosovo by NATO's member States is an example of the 'internationalization of human rights.' In 1999, NATO deployed military forces in response to the armed conflict in Kosovo between Serbian forces and Kosovo Liberation Army. To dissuade civilians from supporting the Kosovo Liberation Army, the Serbian troops massacred civilians in Kosovo. The Security Council requested a cease-fire, but the parties to the conflict

Iancu, Andreea. "The Responsibility to Protect: A Just War Theory Based Analysis". SEA: Practical Application of Science, vol.2, 2014. pp.341-348, at 345. https://seaopenresearch.eu/Journals/articles/SPAS_5_47.pdf. Accessed 8 November 2020.

2 United Nations. "Secretary-General Reflects on 'Intervention' in Thirty-Fifth Annual Ditchley Foundation Lecture". United Nations, 26 June 1998, https://www.un.org/press/en/1998/19980626.sgsm6613.html. Accessed 16 November 2020.

3 Payandeh, Mehrdad. "With Great Power Comes Great Responsibility? The Concept of the Responsibility To Protect Within the Process of International Lawmaking". Yale Journal of International Law, vol. 35, 2010. pp. 470 - 516, at 472. Yale Journal of International Law. https://digitalcommons.law.yale.edu/yjil/vol35/iss2/5/. Accessed 10 November 2020.

4 Pease, Kelly Kate \& David P. Forsythe. "Human Rights, Humanitarian Intervention, and World Politics". Human Rights Quarterly, vol. 15, Issue 2, 1993. pp. $290-314$, at 294 - 295 . Gale OneFile: LegalTrac. link.gale.com/apps/doc/A13917979/LT?u=crepuq_mcgill\&sid=LT\&xid=d70caf5e. Accessed 10 January 2021, (as elaborated by the authors, international law traditionally considered the relation between a state and its citizens to be a domestic affair, falling under the principle of state sovereignty. However, human rights has increasingly become international, especially due to the formation of human right treaties. In 1992, the Security Council also declared that the international community "no longer can allow advancement of fundamental rights to stop at national borders). 
failed to conform. ${ }^{5}$ NATO then militarily intervened in the situation. The intervention was not under the mandate of the Security Council. However, it was seen as legitimate. ${ }^{6}$ Annan, in response to the uproar caused by this intervention, stated: ${ }^{7}$

"if humanitarian intervention is, indeed, an unacceptable assault on sovereignty, how should we respond to Srebrenica, to gross and systematic violations of human rights that offend every precept of our common humanity?".

To some extent, Annan did not condemn the intervention by NATO. However, Klinton W. Alexander noted that such unilateral intervention - intervention without the mandate of the Security Council or involvement of the United Nations could set a dangerous precedent for future intervention without a clear criterion to decide who might invoke these precedents and in what circumstances. ${ }^{8}$

It has been emphasized that the intervention in Kosovo was an infringement of the Security Council's authority in mandating States to maintain international peace and security as enshrined in Article 24(1) of the United Nations Charter (the Charter). It also complicates the discourse of 'right to intervene' and did not give an

\footnotetext{
Alexander, Klinton W. "NATO'S intervention in Kosovo: the legal case for violating Yugoslavia's national sovereignty in the absence of Security Council approval". Houston Journal of International Law, volume 22, number 3, 2000. pp. $403-449$, at $431-$ 433. Gale OneFile: LegalTrac. link.gale.com/apps/doc/A62923792/LT?u=crepuq_mc gill\&sid=LT\&xid=d14ef956. Accessed 10 January 2021, (Security Council's resolution S/Res/1160 in 1998 to request the parties to negotiate and S/Res/1199 in 1998 to order ceasefire and stop violence against civilians were ignored. Despite a brief ceasefire achieved during a meeting with US Special Envoy Richard Holbrook, it was disrupted and the conflict ensued).

6 Scharf, Michael P. "Seizing the Grotian Moment: Accelerated Formation of Customary International Law in Times of Fundamental Change". Cornell International Law Journal, vol. 43, 2010. pp. 439 -469, $\begin{array}{llll}\text { at } & 450 & - & 451 .\end{array}$ https://papers.ssrn.com/sol3/papers.cfm?abstract_id $=1588283$. Accessed 8 November 2020 .
}

explicit criterion for invoking such a right. Interestingly, the Security Council eventually endorsed the intervention in Kosovo. ${ }^{9}$

Additionally, during NATO's campaigns, there have been reports on allegations of international humanitarian law violations by NATO, such as attacks against civilians and civilian objects and attacks against dualpurpose objects used by civilians and armed forces. The matter later was brought to the International Criminal Tribunal for Former Yugoslavia. However, the Office of the Prosecutor concluded that no investigation be commenced to this matter since "either the law is not sufficiently clear or investigations are unlikely to result in the acquisition of sufficient evidence to substantiate charges against high level accused or against lower accused of particularly heinous offenses." 10

Thus, humanitarian intervention, such as in Kosovo, is still up for debate on its legitimacy, framework, result, and accountability. R2P is expected to answer this dissonance between the State's sovereignty, the Charter, and human rights protection. Three pillars are captured within R2P: (i) responsibility to prevent; (ii) responsibility to react; and (iii) responsibility to rebuild. ${ }^{11}$ Its concept may be scrutinized into three parts: (i) States

Annan, Kofi. We the Peoples, United Nations Department of Public Information, 2000, at 47-48.

Alexander, Klinton W, supra note 5, at 439.

Ibid., at 430 .

10 International Criminal Tribunal for Former Yugoslavia. "Final Report to the Prosecutor by the Committee Established to Review the NATO Bombing Campaign Against the Federal Republic of Yugoslavia". International Criminal Tribunal for Former Yugoslavia, https://www.icty.org/en/press/final-reportprosecutor-committee-established-review-natobombing-campaign-against-federal. Accessed 8 November 2020, paras. 58, 63, 71, 80, 86, 90 (attacks against civilians and civilians object allegation are referred to the attacks against civilian passenger train at Grdelica Gorge, attack against the Djakovica Convoy consisted of refugees, attack against the Chinese Embassy, and attack against Korisa Village which was the collateral victims of the attack. Attack against dualpurpose objects is referred to the attack against stateowned radio and TV stations).

11 ICISS. The Responsibility to Protect: The Responsibility to Protect Report of the International Commission on 
have the primary responsibility to protect its population from genocide, ethnic cleansing, war crimes, and crimes against humanity; (ii) international community has the responsibility to assist States to uphold such responsibility, and (iii) international community must use diplomatic measures and other peaceful means to protect such population from such crimes..$^{12}$ If the State fails to fulfill its responsibility or perpetrates such crimes, the international community may take measures, including military intervention, based on the Security Council's mandate. ${ }^{13}$

By emphasizing that sovereignty is responsibility and responsibility to protect human rights is bestowed primarily to States, R2P changed the dynamic of international relations in protecting human rights. It is considered that R2P is essential in reforming the interaction between human rights protection and the international community. Therefore, its status as a custom is necessary to strengthen the human rights protection mechanism.

Custom is universal and non-negotiated as such that custom applies to all legal subjects even if they do not express consent. ${ }^{14}$ Accordingly, the applicability of custom is much more versatile than treaties - custom's counterpart - which only binds State parties. Custom is also less elusive than the general principle of law which still heavily relies on treaties and custom for it

Intervention and State Sovereignty, The International Development Research Centre, 2001, at 19, 29, 39.

12 Resolution Adopted by the General Assembly: 2005 World Summit Outcome, GA Res. UN Doc A/Res/60/1 (2005), para. 139.

13 Weiss, Thomas G. (et.al.). "The Responsibility to Protect: Is Anyone Interested in Humanitarian Intervention?". Third World Quarterly, vol.25, issue 5, 2004. pp. $977-992$, at 978. https://doi.org/10.1080/0143659042000232063. Accessed 9 November 2020.

14 Helfer, Laurence R. \& Ingrid B. Wuerth. "Customary International Law: An Instrument Choice Perspective". Michigan Journal of International Law, vol. 37, 2016. pp. $563-609$, at 569 \& 575. MJIL: Michigan Journal of International Law. https://repository.law.umich.edu/mjil/vol37/iss4/1/. Accessed 10 November 2020 to be recognized. ${ }^{15}$ Therefore, when it comes to R2P and human rights protection, it is imperative to determine R2P as custom, a universal norm recognized by States.

For these reasons, this paper will convey that R2P should be a part of custom based on the analysis in Section II. To realize the potential of R2P as a human rights protection mechanism, this paper will also explore the importance of one of its pillars, the responsibility to prevent. This particular pillar is significant since conflicts that cause human rights violations are avoidable if the root of the disputes can be resolved.

Thus, in Section III, this paper will argue that conflict prevention should be the heart of R2P since it will save the international community the fuss to react to mass atrocities and rebuild the affected population. As a turning point for States, conflict prevention is essential to realize to avoid unnecessary suffering.

\section{B. R2P AS A CUSTOM}

Based on Mario Prost's work, the authors take the notion of "custom primacy thesis," which posits that custom sits higher than treaties. ${ }^{16}$ Grigory Tunkin claimed custom is the only general international law since historically, the only source of international law was custom, and there had not yet sufficient treaties. At that time, treaties were considered to be 'particular norms' since they were only bound to State parties. ${ }^{17}$ The International Court of Justice

15 Yotova, Rumiana. "Challenges in the Identification of the "General Principles of Law Recognized by Civilized Nations": The Approach of the International Court". Canadian Journal of Comparative and Contemporary Law, vol. 3, no. 1, 2017. pp. $269-323$, at 274. SSRN. https://papers.ssrn.com/sol3/papers.cfm?abstract_id =3020190. Accessed 8 November 2020.

16 Prost, Mario. "Hierarchy and the Sources of International Law: A Critique". Houston Journal of International Law, vol. 39, no. 2, 2017. pp.285-330, at 299. Gale OneFile: LegalTrac. link.gale.com/apps/doc/A513193936/LT?u=crepuq_m cgill\&sid=LT\&xid=88812092. Accessed 10 November 2020.

17 Tunkin, Grigory. "Is General International Law Customary Law Only?". European Journal of International Law, vol. 4, 1993. pp. $534-541$, at 535. 
(ICJ) has affirmed that custom is indeed 'general' and does not only bind to certain States. ${ }^{18}$

For the interest of universal human rights protection, custom should sit higher than a treaty which only binds its State parties since custom is considered as general international law and is granted the power to bind all States. Thus, it is argued that R2P should be deemed as a custom by (i) providing the relevance of custom in human rights protection; (ii) elaborating the elements of custom; and (iii) giving state practice and opinio juris to prove R2P should be considered as a custom.

\section{Custom and Human Rights}

It is important to emphasize that custom has advantages over treaties. First, unlike treaties, which only bind State parties, once a norm is established as custom, it is binding on all States, even those new to a type of activity, so long as they did not persistently object during its formation. Second, State parties may withdraw from treaties. However, this is not the case in custom. ${ }^{19}$ As also stated in the Preamble and Article 1(3) of the Charter, promotion of human rights is one of the missions of the international community. Thus, to realize such a

http://www.ejil.org/pdfs/4/1/1216.pdf. Accessed 8 November 2020

18 North Sea Continental Shelf Cases (Germany/Denmark/Netherlands), [1969]. .IC.J. Report of Judgments of 20 February 1969., para. 70 (in the argument of the ICJ, it is stated that "This is to the effect that even if there was at the date of the Geneva Convention no rule of customary international law in favour of the equidistance principle, and no such rule was crystallized in Article 6 of the Convention, nevertheless such a rule has come into being since the Convention, partly because of its own impact, partly on the basis of subsequent State practice, and that this rule, being now a rule of customary international law binding on all States, including therefore the Federal Republic, should be declared applicable to the delimitation of the boundaries between the Parties' respective continental shelf areas in the North Sea.").

19 Scharf, Michael P. "Accelerated Formation of Customary International Law". ILSA Journal of International and Comparative Law, vol. 20, no. 2, 2014. pp. $305-342$, at 309 - 310. SSRN. mission, human rights protection must be based on international norms accepted by all States beyond the applicability of treaties and custom fits such profile.

To be recognized as custom, such legal obligation only needed to be generally accepted by majority States and does not require universal acceptance, but essentially requires a majority of States to "engage in a consistent practice corresponding with the rule. ${ }^{20}$ Such acceptance results in a custom that binds all States, even States who do not express their approval. ${ }^{21}$ Therefore, custom is also needed to bind individual States who tend to be passive in international relations.

\section{The Elements of Custom}

The previous section has proved the significance of custom for human rights protection. It is then important to first understand the elements of custom before analyzing the next section, which will examine the practice of R2P by States and determine whether such practice fulfills the aspects of custom.

Custom arises from a general and consistent practice of States followed by them from a sense of legal obligation. ${ }^{22}$ Custom is formed by state

https://papers.ssrn.com/sol3/papers.cfm?abstract_id $=2479410$. Accessed 9 November 2020 .

20 Robbins, Melissa. "Powerful States, Customary Law and the Erosion of Human Rights Through Regional Enforcement". California Western International Law Journal, vol. 35, no. 2, 2005. pp.275-302, at 292-293. California Western School of Law. https://scholarlycommons.law.cwsl.edu/cwilj/vol35/is s2/5/. 11 November 2020. (the author quoted Oriol Casanovas who argued that "When a majority of states expressly or implicitly demonstrate general acceptance of a rule and a belief in its binding force, a customary rule is born" and Antonio Cassese who stated "General practice does not require universal acceptance, but essentially requires a majority of states to 'engage in a consistent practice corresponding with the rule'.")

21 Ibid.

22 See Posner, Eric A. \& Jack L. Goldsmith. "A Theory of Customary International Law". University of Chicago Law Review, vol. 66, no. 4, 1999. pp. 1113 - 1178, at $292 \quad-\quad 293$. https://chicagounbound.uchicago.edu/cgi/viewconte 
practice and opinio juris - a general recognition by States that the practice is settled enough to amount to an obligation binding on States. ${ }^{23}$ In this paper, attention should be addressed to Roozbeh B. Baker's note that opinio juris is the primary element of a custom and state practice is secondary since legal norm is valid when its subjects believe the norm exists and is an obligation to fulfill. Such belief will be manifested through their actions (state practice). ${ }^{24}$

Maurice $\mathrm{H}$. Mendelson stated that state practice might consist of actions adopted by the legislative, executive, and judicial branch of the Government, administrative officers, judicial decisions, and individuals representing the State. ${ }^{25}$ Ian Brownlie added that diplomatic correspondence, press release, military manuals, and General Assembly resolutions might also be considered state practice. ${ }^{26}$

On the criteria of opinio juris, the ICJ concluded that General Assembly resolutions and state practices, which are based on the belief that such practices are a legal obligation, are considered as opinio juris. ${ }^{27}$ According

nt.cgi?article $=2767 \&$ context=journal_articles.

Accessed 14 November 2020. (The authors were quoting Restatement (Third) of the Foreign Relations Law of the United States).

23 Ibid., at 1116.

24 Baker, Roozbeh B. "Customary International Law in the 21st Century: Old Challenges and New Debates". European Journal of International Law, volume 21, Issue 1, 2010. pp. $173-204$, at $181-182$. Oxford Academic. https://doi.org/10.1093/ejil/chq015. Accessed 12 November 2020; see also: Lefkowitz, David. "The Source of International Law: Some Philosophical Reflections". The Philosophy of International Law, edited by Samantha Besson \& John Tasioulas, Oxford University Press, 2010, at 202; Simma, Bruno \& Philip Alston. "The Sources of Human Rights Law: Custom, Jus Cogens, and General Principles". Australian Yearbook of International Law, vol.12, edited by Philip Alston (et.al.), Australian National University, 1989, at 89 (Bruno Sima and Phillip Alston further added that state practice is only seen as evidence that such custom derived from opinio juris exists).

25 Mendelson, Maurice $\mathrm{H}$. "The Formation of Customary International Law". Collected Courses of the Hague to the ICJ, opinio juris may also be the belief not to take any action towards certain matters. ${ }^{28}$

Additionally, Draft Conclusions on Identification of Customary International Law drafted by the International Law Commission (ILC) provided a more detailed explanation of state practice and opinio juris. Although the draft is not legallybinding, it will be used as the basis of assessing state practice and opinio juris in the practice of R2P and follow the step of Etienne Henry. He used the draft in assessing acquiescence matter in his writing. ${ }^{29}$

The draft stated that state practice consists of the State's conduct in exercising its executive, legislative, judicial, or other functions. To qualify as state practice, the conduct in question must be "of the state," meaning the act of any organ or any person considered as the act of State. The practice must also be known to other States or publicly available. ${ }^{30}$ Forms of state practice include, but are not limited to: diplomatic acts and correspondence; conduct in connection with resolutions adopted by an international

Academy of International Law, vol. 272. Koninklijke Brill NV, 1998, at 198. http://dx.doi.org/10.1163/18758096_pplrdc_A9789041112378_02.

26 Ibid., at 204.

27 Case Concerning Military and Paramilitary Activities in and against Nicaragua (Nicaragua v. United States of America), [1986]. I.C.J. Reports of Judgments: Advisory Opinions and Orders of 27 June 1986, at 100.

28 The Case of the S.S. Lotus (France v. Turkey), [1927]. P.C.I.J.: Judgment No.9 of 7 September 1927, at 28.

29 Henry, Etienne. "Alleged Acquiescence of the International Community to Revisionist Claims of International Customary Law (With Special Reference to the Jus Contra Bellum Regime)". Melbourne Journal of International Law, vol. 18, no. 2, 2017. pp.1 - 38, at 8,13,28. SSRN. https://papers.ssrn.com/sol3/papers.cfm?abstract_id =3097867\#. Accessed 13 November 2020.

30 International Law Commission. "Draft Conclusions on Identification of Customary International Law With Commentaries".

https://legal.un.org/ilc/texts/instruments/english/co mmentaries/1_13_2018.pdf. Accessed 12 November 2020, Conclusion 5 and its Commentaries (2) and (5). 
organization or at an
intergovernmental

conduct in connection with treaties;

executive conduct, including operational conduct "on the ground"; legislative and administrative acts; and decisions of national courts. ${ }^{31}$

Universal participation is not required: it is not necessary to show that all States have participated in the practice in question. The participating States should include those that had an opportunity or possibility of applying the alleged rule. The States must be representative, which needs to be assessed in light of all the circumstances, including the various interests at stake and the different geographical regions. ${ }^{32}$ In assessing generality, it may consider only those States that are mainly involved in the relevant activity or are most likely to be concerned with the alleged rule. ${ }^{33}$

While, evidence of opinio juris may take a wide range of forms, including, but are not limited to: public statements made on behalf of States; official publications; government legal opinions; diplomatic correspondence; decisions of national courts; treaty provisions; and conduct in connection with resolutions adopted by an international organization or at an intergovernmental conference. ${ }^{34}$

\section{Identification of R2P as a Custom}

Following a detailed description of state practice and opinio juris, this section will utilize it to analyze the evidence provided to prove that R2P may be considered a custom. Mehrdad Payandeh has argued that R2P is a de lege feranda norm or a norm that

Ibid., Conclusion 6.

Ibid., Commentaries (9) to Conclusion 8.

Ibid., Commentaries (4) to Conclusion 8.

Ibid., Conclusion 10.

Payandeh, Mehrdad, supra note 3, at 500.

Supra note 18, para. 74 (as noted by the ICJ that short period of time is not necessarily a bar to the formation of custom, but it is important that the state practice should be considered as custom in the future. ${ }^{35}$ However, until the time this paper is written, there is little support to promote R2P as a custom.

However, 'too early' in identifying a practice as a custom is never the case as long as state practice, and opinio juris are present. $^{36}$ Mendelson has also pointed it out through his analogy, "we are more interested in knowing when we bite it if it is now ripe or still too hard or sour." 37 It is hard to tell when the fruit becomes ripe. It would be difficult to pinpoint the exact moment a practice becomes a legal obligation as a custom. Thus, we cannot definitively say that an approach is or is not a custom until an anonymous State agreement or a decision by a court is established that such practice is a custom.

Therefore, the following two subsections will contribute to the promotion of R2P as a custom by: (i) arguing that the formation of $\mathrm{R} 2 \mathrm{P}$ is a 'Grotian moment' due to R2P's nature as a paradigm-shifting development in which new rules and doctrines of custom emerge with unusual rapidity and acceptance and (iii) analysing based on the standard provided by the ILC draft and how the research is affected by the notion Grotian moment.

a. Grotian Moment Consideration in Formulating R2P as a Custom

Michael P. Scharf stated that the formation of custom might be affected by a third factor, in addition to state practice and opinio juris, which is a context of fundamental change, triggering a more rapid formation of custom and needing the fewer amount of state practice. ${ }^{38}$ Grotian moment is

should have been both extensive and virtually uniform in the sense of the provision invoked and should moreover have occurred in such a way as to show a general recognition that a rule of law or legal obligation is involved).

37 Scharf, Michael P. supra note 19, at 330.

$38 \quad$ Ibid., at $306-307$ 
a term that denotes this paradigmshifting development in which new rules and doctrines of custom emerge with unusual rapidity and acceptance. $^{39}$

The formation of R2P was motivated by the difference of opinion regarding what to do in responding to mass atrocities at that time, especially those during the 1990s, from the civil war in Rwanda to mass atrocities in Kosovo and Sierra Leone. NATO's intervention in Kosovo in 1999 is seen as a stepping stone for the formation of R2P and viewed as a Grotian moment by Scharf. ${ }^{40}$

The formation of R2P is a Grotian moment since R2P became the new benchmark in understanding sovereignty. R2P shifted the concept of sovereignty, which was initially seen as rights and as an absolute boundary to domestic affairs to, currently, similar to responsibility and recognition that human rights are also a matter of international concern. R2P changed the practice of intervention to institutionalize intervention into the United Nations' system. Alex J. Bellamy stated that R2P differed from the older concept of humanitarian intervention and it introduced a novel idea on human rights protection. He added that R2P has become a diplomatic language of humanitarian emergencies. ${ }^{41}$ Therefore, the determination of

39 Scharf, Michael P. supra note 6, at 440.

40 Ibid., at 450. (Scharf took the formation of R2P as an example of a recent Grotian moment where it was triggered by NATO's intervention in Kosovo. Commentators labelled the intervention as "unlawful but legitimate" prompting the General Assembly and Security Council to adopt R2P which would authorize humanitarian intervention in certain limited circumstances in the future).

41 Bellamy, Alex J. "The Responsibility to Protect: Five Years On". Ethics \& International Affairs, vol. 24, no. 2, 2010. pp. 143 - 169, pp. 143 - 144. Wiley Online
R2P as a custom may be based on its status as a Grotian moment.

The concept may help a court examine whether a particular General Assembly resolution should be deemed evidence of an embryonic rule of custom, especially in a case lacking the traditional level of widespread and repeated state practice..$^{42}$ In periods of fundamental change, rapidly developing custom is crystallized in General Assembly resolutions, which may be necessary for international law to keep up with. ${ }^{43}$ General Assembly resolutions can declare existing customs or crystallize emerging customs. A 1975 United States Department of State pronouncement explained that General Assembly resolutions are meant to be declaratory of international law, are adopted with the support of all members, and are observed by states' practice. Such resolutions are evidence of customary international law on a particular subject matter. ${ }^{44}$

The ICJ has affirmed that General Assembly resolutions have legal significance as new custom evidence. In deciding whether to treat a particular General Assembly resolution as evidence of a new custom, the ICJ has stated that "it is necessary to look at the resolution's content and the conditions of its adoption." 45 General Assembly resolutions fall within a spectrum, from mere recommendations

Library.

https://onlinelibrary.wiley.com/doi/full/10.1111/j.17 47-7093.2010.00254.x. Accessed 14 November 2020.

42 Scharf, Michael P. supra note 6, at 450.

43 Ibid. (Scharf illustrated that 'period of fundamental change' may be caused whether by technological advances, the commission of new forms of crimes against humanity, or the development of new means of warfare or terrorism).

$44 \quad$ Ibid., at 448.

$45 \quad$ Ibid., at $448-449$. 
(usually given little weight) to declarations (used to impart increased solemnity) to affirmations (used to indicate codification or crystallization of law). Courts also consider the words used in the resolution, for example, the language of firm obligation versus aspiration. Another consideration is the vote outcome. ${ }^{46}$ However, it is essential to note that the Grotian moment concept looks beyond General Assembly resolutions and focuses on paradigmatic changes in international law caused by rapid and profound global developments. ${ }^{47}$

Noting how significant General Assembly resolutions are to the status of R2P as a custom based on the Grotian moment concept, it is essential to examine the content and conditions surrounding the resolutions which include R2P. This examination supports Baker's opinion as quoted above in assessing the elements of custom; one must primarily concern more about the opinio juris, which is often reflected in General Assembly resolutions.

Members of the General Assembly anonymously accepted $\mathrm{A} / \mathrm{Res} / 60 / 1$ in 2005 and $\mathrm{A} / \mathrm{Res} / 63 / 308$ in 2009. These resolutions are adopted without abstaining and refusal. The language within these resolutions indicates consent to the commitment of all State members Legal Theory of Statehood". Denver Journal of International Law \& Policy, vol.39, no. 2, 2011. pp. 209 - 238, at 213. Gale OneFile: LegalTrac. link.gale.com/apps/doc/A253224328/LT?u=crepuq_m cgill\&sid=LT\&xid=48ff7acc. Accessed 12 November 2020.

$48 \quad$ Supra note 12 , para. 138.
}

of the General Assembly towards $\mathrm{R} 2 \mathrm{P}$ as a legal obligation.

In paragraph $138 \mathrm{~A} / \mathrm{Res} / 60 / 1$, it is explicitly stated that "Each State has the responsibility to protect its populations from genocide, war crimes, ethnic cleansing and crimes against humanity" and "We accept that responsibility and will act in accordance with it" as well as "The international community, through the United Nations, also has the responsibility to use appropriate diplomatic, humanitarian and other peaceful means ...". 48

In $A / \operatorname{Res} / 63 / 308$, it referred to $A /$ Res/60/1 by stating, "recalling the 2005 World Summit Outcome, especially paragraphs 138 and 139...". ${ }^{49}$ Additionally, the General Assembly also adopted A/RES/69/323 in 2015 that stated, "Reiterating the responsibility of each State to protect its populations from genocide, which entails the prevention of such a crime, including incitement to it, through appropriate and necessary means, and that fighting impunity for the crime of genocide is an important factor in its prevention...". .50

The language used in these resolutions is an indication that all State members of the General Assembly recognized R2P as a legal obligation. The adoption of A/Res/60/1 after four years from ICISS's first introduction of R2P in 2001 and later followed by the adoption of $A / \operatorname{Res} / 63 / 308$ in 2009 and $A / R E S / 69 / 323$ in 2015 indicate

49 Resolution Adopted by the General Assembly on 14 September 2009, GA Res. UN Doc. A/Res/63/308 (2009), at 1.

50 International Day of Commemoration and Dignity of the Victims of the Crime of Genocide and of the Prevention of This Crime, GA Res. UN Doc. A/Res/69/323 (2015), at 1 (this resolution too was adopted anonymously, without abstaint or refusal). 
a universal consent in a short period given by members of the General Assembly on R2P.

Hence, the formation of R2P fits the profile to be a Grotian moment: (i) it was accepted, anonymously, by States based on the content and conditions of the relevant General Assembly resolutions and (ii) R2P fundamentally changed how the international community should understand the relation between State's sovereignty and human rights protection. As described above, Grotian moment concept 'compensates' R2P from the traditional burden of state practice and opinio juris since the concept focuses more on the paradigmatic changes in international law caused by rapid and profound formation of R2P. The Grotian moment status lowers the standard to form and prove a custom. In examining the evidence of state practice and opinio juris in the next section, it will be unnecessary to examine all States due to R2P's status as a Grotian moment.

b. State Practice and Opinio Juris in R2P Practice

To prove that R2P should be seen as a custom and it emerged with unusual rapidity and acceptance, this section will analyze the fulfillment of elements of custom in the practice of $\mathrm{R} 2 \mathrm{P}$.

Noting the ILC draft and Brownlie's earlier contention, conduct in connection with resolutions adopted by an international organization may be deemed state practice or opinio juris. So as not to become a repetition, the general consent of States in $A / \operatorname{Res} / 60 / 1$, $\mathrm{A} / \mathrm{Res} / 63 / 308$, and A/RES/69/323 will be concluded as state practice and opinio juris due to its formations' circumstances and language and must not be overlooked throughout this section. First, the practice of Australia. In 2008, the Senate Standing Committee on Foreign Affairs, Defence and Trade of Australia made a report regarding the implications of R2P in decisionmaking. The committee believes that the Government should continue to encourage the international community to move forward by adopting guidelines for the implementation of R2P. ${ }^{51}$ In its 2018 - 2019 report, the Department of Foreign Affairs and Trade of Australia also stated that they support R2P, which seeks to protect vulnerable populations from genocide, ethnic cleansing, war crimes, and crimes against humanity. They have worked in partnership to engage ASEAN and Pacific countries on early warning for conflict and atrocity prevention, supporting, for example, a new youth network that has been tackling local drivers of conflict such as hate speech. ${ }^{152}$

Such support is also reflected in Australia's role as non-permanent members of the Security Council in 2013 - 2014. Australia accepted the reiteration of R2P as States'

\footnotetext{
Senate Standing Committee on Foreign Affairs, Defence and Trade of Australia. "Australia's Involvement in Peacekeeping Operations". Parliament of Australia, 26 August 2008, , at 64. https://www.aph.gov.au/Parliamentary_Business/Co mmittees/Senate/Foreign_Affairs_Defence_and_Trad e/Completed_inquiries/2008-

10/peacekeeping/report/index. Accessed 16 November 2020.
}

52 Department of Foreign Affairs and Trade of Australia. "Department of Foreign Affairs and Trade Annual Report 2018-19". Australian Government, Department of Foreign Affairs and Trade, at 83. https://www.dfat.gov.au/aboutus/publications/corporate/annualreports/Pages/department-of-foreign-affairs-andtrade-annual-report-2018-19. Accessed 16 November 2020. 
Establishing the Status of Responsibility to Protect (R2P) as Customary International Law and Its Role in Preventing Mass Atrocities

responsibility in S/RES/2117 on small arms and light weapons $\mathrm{s}^{53}$ and $\mathrm{S} / \mathrm{RES} / 2150$ on threats to international peace and security. ${ }^{54}$

Second, the practice of Norway. In 2019, the Norwegian Permanent Mission to the United Nations in New York stated that Norway continues to be firmly committed to R2P and that "upholding our collective responsibility to protect must remain at the center of our commitment to an international rules-based order."155 Norwegian Ministry of Foreign Affairs also published its 2014 - 2015 report, which stated the Government endorses this broad range of tools provided in R2P. ${ }^{56}$ Norway is one of the States which accepted the adoption of $A / \operatorname{Res} / 60 / 1$, $\mathrm{A} / \mathrm{Res} / 63 / 308$, and $\mathrm{A} / \mathrm{RES} / 69 / 323$ as described above.

Third, the practice of Turkey. In 2012, Ahmet Davutoğlu, Minister of Foreign Affairs of Turkey, stated, in relation with the situation in Syria, noting, "The responsibility to

$53 \quad$ Resolution 2117 (2013), SC Res UN Doc. S/Res/2117 (2013).

54 Resolution 2150 (2014), SC Res UN Doc. S/Res/2150 (2014).

55 Norwegian Permanent Mission to the United States in New York. "GA: The Responsibility to Protect". Norwegian Permanent Mission to the United States in New York, https://www.norway.no/en/missions/UN/statements /general-assembly-plenary/2019/ga-theresponsibility-to-protect/. Accessed 17 November 2020.

56 Norwegian Ministry of Foreign Affairs. "Opportunities for All: Human Rights in Norway's Foreign Policy and Development Cooperation", at 66. https://www.regjeringen.no/contentassets/261f255d 028b42cab91ad099ee3f99fc/en-

gb/pdfs/stm201420150010000engpdfs.pdf. Accessed 17 November 2020.

57 Ministry of Foreign Affairs of Turkey. "Address by Mr. Ahmet Davutoğlu, Minister of Foreign Affairs of Turkey at the 67th United Nations General Assembly, 28 September 2012, New York". Republic of Turkey, Ministry of Foreign Affairs, http://www.mfa.gov.tr/address-by-mr_-ahmetdavutoglu_-minister-of-foreign-affairs-of-turkey-atthe-67th-united-nations-general-assembly_-28september.en.mfa. Accessed 17 November 2020. protect the people of Syria is our fundamental duty."157 In 2009, Turkey also made a statement stating, "The responsibility to protect populations from genocide, war crimes, ethnic cleansing and crimes against humanity rests primarily with the States." ${ }^{58}$ Like Norway, Turkey is also one of the States that accepted the adoption of $A / \operatorname{Res} / 60 / 1, A / \operatorname{Res} / 63 / 308$, and A/RES/69/323.

Fourth, the practice of the United Kingdom. In 2010, the Foreign and Commonwealth Office, the Department for International Development, and the Ministry of Defence of the United Kingdom launched a national strategy to protect civilians in armed conflicts. It explicitly stated that States have the primary responsibility for protecting and meeting the basic needs of their civilians in times of armed conflict and peace. ${ }^{59}$ Its contribution in the Security Council shows United Kingdom's attitude as it accepted the inclusion of R2P in,

58 Turkey's Permanent Mission to the United Nations. "Address by Mr. Fazlı Çorman Charge D'Affaires a.i. and Deputy Representative of Turkey to the UN, "Responsibility to Project" UN General Assembly, 63rd Session". Turkey's Permanent Mission to the United Nations, 24 July 2009, http://turkuissue dt.mfa.gov.tr/Mission/ShowSpeech/1183. Accessed 18 November 2020.

59 Department for International Development, Foreign and Commonwealth Office \& Ministry of Defence. "UK Government Strategy on the Protection of Civilians in Armed Conflict", at 4. https://assets.publishing.service.gov.uk/government/ uploads/system/uploads/attachment_data/file/32950 /ukstrategy-protect-cvilians-arms-conflict.pdf.

Accessed 19 January 2021. (specifically it stated "A number of actors share the moral, legal and practical responsibility for the protection of civilians. However, by virtue of their sovereignty a state has the primary responsibility for protecting and meeting the basic needs of its civilians in times of armed conflict as well as peace. When a state manifestly fails to protect its population from genocide, war crimes, ethnic cleansing or crimes against humanity, the international community has a responsibility to act. This principle is enshrined in the concept of Responsibility to Protect"). 
for example, S/RES/1970 on the situation in Libya, ${ }^{60}$ S/RES/2155 on the situation in South Sudan, ${ }^{61}$ and S/RES/2419 on the maintenance of international peace and security. ${ }^{62}$

Additionally, in September 2013, the United Kingdom mission to the United Nations ambassador stated that "R2P should be an important governing principle of all countries' work across the conflict spectrum, as well as on human rights and development". ${ }^{63}$ Moreover, the United Kingdom Foreign Affairs committee's report in 2018 on the humanitarian crisis in Syria also stated that "The U.K. remains firmly committed to the Responsibility to Protect (R2P) concept and to doing all we can to prevent, or where necessary, response to atrocities. We disagree with the Inquiry's recommendation that the Government should adopt a new atrocity prevention strategy." ${ }^{164}$

In the report, the committee admitted the Government's commitment to R2P. It stated that another atrocity prevention strategy is unnecessary due to the existence of R2P, which may conclude the committee believe that R2P should be the only atrocity

60 Resolution 1970 (2011), SC Res UN Doc. S/Res/1970 (2011).

61 Resolution 2155 (2014), SC Res UN Doc. S/Res/2155 (2014).

62 Resolution 2419 (2018), SC Res UN Doc. S/Res/2419 (2018).

63 Ralph, Jason. "Mainstreaming the Responsibility to Protect in UK Strategy - Improving the Government's Response to the Threat of Mass Atrocity", at 18. https://una.org.uk/sites/default/files/UNA-

UK\%20Policy\%20briefing\%202\%20-\%20Professor\%20J ason\%20Ralph\%20-\%20Mainstreaming\%20R2P\%20in \%20UK\%20strategy.pdf. Accessed 19 November 2020.

64 Foreign Affairs Committee. "Global Britain: The Responsibility to Protect and Humanitarian Intervention: Government response to the Committee's Twelfth Report". 19 November 2018, https://publications.parliament.uk/pa/cm201719/cms elect/cmfaff/1719/171902.htm. Accessed 19 November 2020.

prevention strategy. ${ }^{65}$ Thus, the United Kingdom committed to the practice of R2P and recognized that it should be the only mechanism in dealing with mass atrocities.

Fifth, in 2015, the United States released its national security strategy, which stated, "We affirm our support for the international consensus that governments have the responsibility to protect civilians from mass atrocities and that this responsibility passes to the broader international community when those governments manifestly fail to protect their populations." ${ }^{166} \quad$ Additionally, Delegation of the United States in the Human Rights Council 20th Session in 2012 also stated that the United States was then and is now a strong supporter of the concept of R2P. ${ }^{67}$

Elaine French, Deputy Political Coordinator for the United States mission to the United Nations, also remarked that "We continue to support the 2005 World Summit outcome document and believe that each state has the responsibility to protect its populations from genocide, war crimes, ethnic cleansing, and crimes against humanity. ${ }^{168}$

United States of America. "National Security Strategy", at

https://obamawhitehouse.archives.gov/sites/default/ files/docs/2015_national_security_strategy_2.pdf. Accessed 20 November 2020.

67 United States of America Mission in Geneva. "The U.S. Strongly Supports the Concept of Responsibility to Protect (R2P)". United States of America Mission in Geneva,

https://geneva.usmission.gov/2012/06/19/the-u-sstrong-supporter-of-the-concept-of-responsibility-toprotect-r2p/. Accessed 20 November 2020.

68 United States of America Mission to the United Nations. "Remarks at a UN General Assembly Debate on Responsibility to Protect". United States Mission to the United Nations, https://usun.usmission.gov/remarks-at-a-un-generalassembly-debate-on-responsibility-to-protect/. Accessed 23 November 2020. 
Establishing the Status of Responsibility to Protect (R2P) as Customary International Law and Its Role in Preventing Mass Atrocities

As for the state practice, Elaine French added that "on January 14, 2019, the Elie Wiesel Genocide and Atrocities Prevention Act came into law, reaffirming the U.S. commitment to preventing and responding to atrocities. This legislation highlights the importance of a coordinated "whole of government" approach to strengthen our Government's ability to forecast, prevent, and respond to mass atrocities." ${ }^{169}$ In 2020, the Bureau of Conflict and Stabilization Operations reported to Congress on the implementation of the Elie Wiesel Act. It highlighted the progress, accomplishments, and steps taken to prevent and respond to atrocities during the period. ${ }^{70}$ Thus, from state practice and opinio juris perspective, the United States soundly supports and acknowledges R2P as a part of the State's obligation.

Sixth, the Russian approach towards R2P is, at best, that of reservation and hesitation, as stated by Dogachan Dagi. ${ }^{71}$ However, Russia does not want to appear objecting to the idea of saving vulnerable populations from

69 Ibid; see also: S.1158 - Elie Wiesel Genocide and Atrocities Prevention Act of 2018, 115th Congress of the United States of America Public Law 441.

70 Bureau of Conflict and Stabilization Operations. "2020 Report to Congress Pursuant to Section 5 of the Elie Wiesel Genocide and Atrocities Prevention Act of 2018". U.S. Department of State, 7 August 2020, https://www.state.gov/2020-Report-to-CongressPursuant-to-Section-5-of-the-Elie-Wiesel-Genocideand-Atrocities-Prevention-Act-of-2018. Accessed 22 November 2020.

71 Dagi, Dogachan. "The Russian Stand on the Responsibility to Protect: Does Strategic Culture Matter?". Journal of Asian Security and International Affairs, vol. 7, no. 3, 2020. pp. $370-386$, at 378. SAGE Journals.

https://journals.sagepub.com/doi/full/10.1177/23477 97020962667. Accessed 20 November 2020.

72 Ibid., at 379.

73 Resolution 1894 (2009), SC Res UN Doc. S/Res/1894 (2009), at 1; supra note 64, at 2.

74 Resolution 2134 (2014), SC Res UN Doc. S/Res/2134 (2014), paras. 30,32. mass atrocities. Still, it questions the need for crafting R2P as an international norm to respond to mass atrocities. ${ }^{72}$ Thus, Russia endorsed R2P but with a caution of its interpretation.

This support reflected on its vote for Security Council's Resolution S/Res/1894 on the protection of civilians in armed conflict and S/Res/1970 in 2011 on Libya's situation, which both reaffirmed the responsibility of States to practice R2P. ${ }^{73}$ Russia also voted for S/Res/2134 in 2014 on the Central African Republic situation, which called for the military intervention of European Union's member's forces. ${ }^{74}$ Thus, although reluctant, Russia has not yet rejected R2P. Instead, it supports and practices R2P despite its careful approach and endorses R2P through its position as one of the Security Council members.

Seventh, China, as written by Catherine Gegout and Shogo Suzuki, is acquiescence to R2P. ${ }^{75}$ 'Acquiescence' has been explained by the ICJ in the Temple of Preah Vihear case. $^{76}$ Accordingly, if a State, while knowing the existence

75 Gegout, Catherine \& Shogo Suzuki. "China, Responsibility to Protect, and the Case of Syria - From Sovereignty Protection to Pragmatism". Global Governance, vol. 26, 2020. pp. $379-402$, at 384. Brill. https://doi.org/10.1163/19426720-02603002. Accessed 21 November 2020.

76 Case Concerning the Temple of Preah Vihear (Cambodia v. Thailand), [1962]. I.C.J. Reports Of Judgments, Advisory Opinions and Orders of 15 June 1962, at 21. (it is in the argument of the ICJ that "It has been contended on behalf of Thailand that this communication of the maps by the French authorities was, so to speak, ex parte, and that no formal acknowledgment of it was either requested of, or given by, Thailand. In fact, as will be seen presently, an acknowledgment by conduct was undoubtedly made in a very definite way; but even if it were otherwise, it is clear that the circumstances were such as called for some reaction, within a reasonable period, on the part of the Siamese authorities, if they wished to disagree with the map or had any serious question to raise in regard to it. They did not do so, either then or for many years, and thereby must be held to have acquiesced. 
of a particular practice, does not react or raise questions towards it and such State can do so but not do so, such State is liable for acquiescence. If China does not respond or deny the practice of R2P but is in a position to do so, for example, as one of the Security Council members, China must be held to have consented to R2P. Additionally, China endorsed the practice of R2P, for example, in S/RES/1975 in 2011 on the situation in Côte d'Ivoire ${ }^{77}$ and S/RES/2085 in 2012 on the situation in Mali. ${ }^{78}$ Thus, by voting for the Security Council's resolutions on the practice of R2P, China revealed its approach is more than just moderate.

Eighth, in 2012, the Foreign Affairs Department of France published a humanitarian strategy which stated, "France attaches particular importance to the responsibility to protect" (R2P) principle, which was endorsed by the international community during the World Summit of September 2005 (Paragraphs 138-140 of the Outcome document) and taken up by the Security Council (particularly in Resolution 1674 of April 28, 2006, on "Protection of civilians in armed conflict")." ${ }^{179}$ Further, it reiterated that R2P binds States to a duty to protect their population. It recognized that the international

Qui tacet consentire videtur si loqui debuisset ac potuisset").

77 Resolution 1975 (2011), SC Res UN Doc. S/Res/1975 (2011), at 2.

78 Resolution 2085 (2012), SC Res UN Doc. S/Res/2085 (2012), at 4 \& 6 .

79 Foreign Affairs Department of France. "France Humanitarian Strategy", at 14. https://www.diplomatie.gouv.fr/IMG/pdf/Strategie Humanitaire_ANGlais_2012_cle89af5f-1.pdf. Accessed 21 November 2020.

80 Ibid.

81 Ministry of Defence of France. "French White Paper on Defence and National Security", at 50. https://www.defense.gouv.fr/content/download/215 community has to assist States in fulfilling such duty and take actions if the situation allows. ${ }^{80}$

In 2013, France published a French White Paper on Defence and National Security, which emphasized that France has a responsibility to protect the French population and contribute to freedom of navigation and the combat against piracy and human trafficking. ${ }^{81}$ France also co-drafted most Security Council's resolutions referring to R2P, such as S/Res/2085 on Mali, ${ }^{82}$ S/Res/2093 on Somalia, ${ }^{83} \mathrm{~S} / \mathrm{Res} / 2196$ on the Central African Republic, ${ }^{84}$ and $\mathrm{S} / \operatorname{Res} / 2211$ on the Democratic Republic of Congo. ${ }^{85}$ Thus, it is clear from the outset that France endorses the existence of R2P and practices it.

Additionally, the practice of international organizations also contributes to the formation or expression of custom. ${ }^{86}$ Since the ILC draft gave European Union as an example for international organizations, it may be assumed that international organizations here may also mean regional organizations. African Union is one of the regional organizations committed to implement R2P. Such commitment is cemented in Ezulwini Consensus 2005 adopted by the Union and United Nations to implement R2P. ${ }^{87}$ In practicing R2P,

253/2394121/White\%20paper\%20on\%20defense\%20 \%202013.pdf. Accessed 22 November 2020.

82 Supra note 82 , at $4 \& 6$.

83 Resolution 2093 (2013), SC Res UN Doc. S/Res/2093 (2013), at 2.

84 Resolution 2196 (2015), SC Res UN Doc. S/Res/2196 (2015), at 1.

85 Resolution 2211 (2015), SC Res UN Doc. S/Res/2211 (2015), at 1.

86 International Law Commission, supra note 30, Conclusion 4(2).

87 Hodali, Augustin. "The Implementation of the Responsibility to Protect Norms by the African Standby Force in Sub-Saharan African". A thesis presented to the Faculty of the U.S. Army Command and General 
African Union also formed African Standby Force to protect the civilians in armed conflicts. ${ }^{88}$ African Union has been involved in interventions relating to $\mathrm{R} 2 \mathrm{P}$, such as in South Sudan, the Democratic Republic of Congo, Central African Republic, and Libya. ${ }^{89}$

European Union is also the regional organization that implements R2P. European Commission and European Parliament expressly recognize R2P as a norm in international law. ${ }^{90}$ European Union is also committed to implement R2P as written in Global Strategy for the European Union's Foreign and Security Policy 2016. ${ }^{91}$ European Union has participated in intervention in the scope of R2P in the Democratic Republic of Congo, Central African Republic, and Chad. ${ }^{92}$ Thus, from a regional organization's perspective, R2P is also recognized as a legal obligation and has been practiced by the organizations.

Recalling the ILC draft provision on state practice, the practice of United Kingdom, United States, France, China, and Russia above are also served as evidence of state practice from States which are "particularly involved in the relevant activity or are most likely to be concerned with the alleged rule" or "have the interest at stake" since these 5 States are permanent members of the Security Council which is bestowed the power to give the mandate to intervene in the scope of R2P. Additionally,

Staff College in partial fulfillment of the requirements for the degree master of military art and science. University of Amsterdam, 2017, at 20.

$88 \quad$ Ibid., at 21.

$89 \quad$ Ibid., at 43 \& 51; see also: Resolution 2031 (2011), SC Res UN Doc. S/Res/2031 (2011), at 2; Resolution 1973 (2011), SC Res UN Doc. S/Res/1973 (2011), at 2.

90 Steenbrink, Laura. "Responsibility to Protect At Stake: R2P in Relation to the US, NATO, and the EU: The Case based on the ILC draft, all of the state practices above may be considered a representation from various geographical regions, from Oceania, America, Europe, Scandinavia, and Asia.

Based on the analysis above, these state practices and opinio juris are considered evidence that R2P should be regarded as a custom based on the ILC draft and the notion, Grotian moment, as R2P emerged with unusual rapidity and acceptance.

\section{R2P IN PREVENTING MASS ATROCITIES}

Following the arguments and evidence that R2P is a custom, its status as a custom should be accompanied by a proper understanding of the spirit of R2P. Thus, in this section, the main argument is that in protecting human rights, States must focus more on the prevention side of R2P. By dealing with the root cause before it escalates, States may avoid unnecessary conflict.

One of the pillars of R2P is a responsibility to prevent. ICISS stated that the responsibility to prevent is eradicating the root of mass atrocities, such as poverty, corruption, misrule, and discrimination. ${ }^{93}$ Duty to prevent must be done according to three elements: (i) early warnings, which indicates warnings to a potential grave violation of human rights based on an assessment on the phenomena within the society conducted by the government or non-governmental organization; toolbox, which becomes the tool for the government in preventing a grave violation of human rights consists of policy and the

of Syria". A thesis presented for the degree MA International Relations in Historical Perspective Utrecht University. Utrecht University, 2017, at 40.

91 European External Action Service, Shared Vision, Common Action: A Stronger Europe, Global Strategy for the European Union's Foreign and Security Policy, Brussel: European External Action Service, 2016, at 42.

92 Steenbrink, Laura, supra note 94 , at 41.

93 ICISS, supra note 11 , at XI,22,29. 
availability of infrastructure, including human rights enforcement mechanism through national mechanism or international law mechanism; and (iii) political will or the willingness to implement the policy. ${ }^{94}$

To understand how those three elements should be implemented and to understand the significance of conflict prevention, Section $I I(A)$ and $I I(B)$ will discuss, respectively: (i) the elements of responsibility to prevent and (ii) the importance of preventing mass atrocities based on a pacifist perspective.

\section{Responsibility to Prevent}

Note that this section will only focus on the effort which should be made by the government, not the United Nations or other international or regional organization since the first level of responsibility to prevent is at the government level. Thus, it is vital to elaborate more on the government's effort to prevent mass atrocities.

Regarding early warnings, one of the state's concerns should be the root cause. To address root cause prevention, it may mean addressing political needs and deficiencies, which might involve constitutional powersharing or redistribution, support press freedom and the rule of law, and promotion of civil society. ${ }^{95}$ The decentralization or centralization of power, drastic reform in administration matter, and more robust law enforcement on corruption, collusion, and nepotism are also significant. The

\section{Ibid., at 20}

Ibid., at 23

96 Bellamy, Alex J. \& Paul D. Williams. "The new politics of protection? Côte d'Ivoire, Libya and the responsibility to protect". International Affairs, vol. 87, no. 4, 2011, pp. 825 - 850, at 829 . https://ciaotest.cc.columbia.edu/journals/riia/v87i4/f _0022933_18802.pdf. Accessed 20 November 2020,; Sekulic, Aleksandar. "Responsibility to Protect and Its Effect on Humanitarian Intervention: Libya, Côte d'Ivore, and Syria". A thesis presented for the degree MA in human rights Central European University. Central European University, 2013, at 41-42. situation in Côte d'Ivoire in 2010, which was later referred to the International Criminal Court, was caused by the presidential election turned violent. ${ }^{96}$ Thus, tackling political issues are essential to prevent mass atrocities.

Root cause prevention may also mean tackling economic deprivation and the lack of economic opportunities, which might involve addressing and resolving inequities in the distribution of resources or opportunities, promoting economic growth and opportunity and better terms of trade, and permitting more generous access to external markets for developing economies. ${ }^{97}$ The situation in Syria since 2011 is a depiction of an economic issue turned violent due to poverty, among other factors. ${ }^{98}$

Root cause prevention may also mean strengthening legal protections and institutions. This might involve supporting efforts to protect the judiciary's integrity and independence, promoting honesty and accountability in law enforcement, enhancing protections for vulnerable groups, especially minorities, and providing support to local institutions and organizations working to advance human rights. ${ }^{99}$ For example, the situation in the Central African Republic in 2012 represented a conflict between majority and minority religious groups, which pushed the Security Council to form a National Special Criminal Court to hold trials for the atrocities. ${ }^{100}$

98 Human Rights Watch. "Syria Events of 2017". www.hrw.org/worldreport/2018/countrychapters/Syria. Accessed 21 November 2020.

$99 \quad \mathrm{ICISS}$, supra note 11 , at 23.

100 Global Centre for the Responsibility to Protect. "Reinforcing the Responsibility to Protect in the Central African Republic", at 2 - 3. http://www.globalr2p.org/media/files/2015-marchcar-brief.pdf. Accessed 22 January 2021; see also: Resolution 2217 (2015), SC Res UN Doc. S/Res/2217 (2015), at 2. 
Root cause prevention may also mean embarking upon sectoral reforms to the military and other state security services. This might involve enhanced education and training for military forces, reintegration of ex-combatants, encouraging efforts to ensure that security services are accountable for their actions and operate within the law, and promoting adherence to arms control and disarmament and nonproliferation regimes, including control over the transfer of light weapons and small arms, and the prohibition of landmines. ${ }^{101}$

Regarding the toolbox, political and diplomatic direct prevention measures may include the direct involvement of the United Nations Secretary-General and fact-finding missions, friends groups, eminent person commissions, dialogue and mediation through good offices, international appeals, and nonofficial "second track" dialogue and problem-solving workshops. At the opposing end of the scale, political and diplomatic direct prevention might encompass the threat or application of political sanctions, diplomatic isolation, suspension of organization membership, travel and asset restrictions on targeted persons, "naming and shaming," and other such actions. ${ }^{102}$

Economic direct prevention measures may again include positive as well as negative inducements. Positive inducements might consist of promises of new funding or investment or the guarantee of more favorable trade terms. Economic direct prevention efforts may also be more coercive, including threats of trade and financial sanctions, withdrawal of investment; threats to withdraw International Monetary Fund or World Bank support;

ICISS, supra note 11 , at 23.

Ibid.

Ibid., at 24 and the curtailment of aid and other assistance. ${ }^{103}$

A spectrum of direct prevention measures of a more legal nature can also be employed. On the one hand, these measures might include offers of mediation, or arbitration, or perhaps adjudication - though, in cases of a domestic dispute, these options may not be readily available or acceptable to all parties. The deployment of monitors to observe compliance with human rights standards, and help reassure communities or groups that feel at risk, is another measure that might usefully be considered. ${ }^{104}$

The scope for direct prevention measures of a military nature is more limited. This might include stand-off reconnaissance, or in particular, a consensual preventive deployment. In extreme cases, direct prevention might involve the threat to use force. ${ }^{105}$ The use of threats and other coercive measures is also much more likely to engender greater political resistance from the targeted state than would prevention based on positive inducements. Nonetheless, tough threatened direct prevention efforts can be significant in eliminating the need to resort to coercive measures, including the use of force. ${ }^{106}$

As to political willingness, preventing, averting, and halting human suffering, all the catastrophic loss and misery that go with slaughter and ethnic cleansing, and mass starvation are inspiring and legitimizing motives in almost any political environment. Political leaders often underestimate the sheer sense of decency and compassion that prevails in their electorates, at least when people's attention is engaged (just as they also underestimate the public will,

4 Ibid.

105 Ibid., at 25.

106 Ibid. 
when well informed, to accept the risk of casualties in well-designed military interventions aimed at alleviating that suffering)-getting a moral motive to bite means, however, being able to convey a sense of urgency and reality about the threat to human life in a particular situation. ${ }^{107}$

The best financial argument is that earlier action is always cheaper than later action. If prevention is possible, it is likely to be less expensive by many orders of magnitude than responding after the event through military action, humanitarian relief assistance, postconflict reconstruction, or all three. ${ }^{108}$

Lastly, national interest appeals can be made at many different levels. Avoiding a neighbor's disintegration, with the refugee outflows and general regional security destabilization associated with it, can be a compelling motive in many contexts. National economic interests often can be equally well served by keeping resource supply lines, trade routes, and markets undisrupted. And whatever may have been the case in the past, peace is generally regarded as much better for business than war. ${ }^{109}$

Another dimension of the national interest is highly relevant to intervention for human protection purposes: every country's national interest in being, and being seen to be, a good international citizen. There is much direct reciprocal benefit to be gained in an interdependent, globalized world where nobody can solve all their problems: "My country's assistance for you today in solving your neighborhood refugee and terrorism problem might reasonably lead you to be more willing to help solve my environmental or

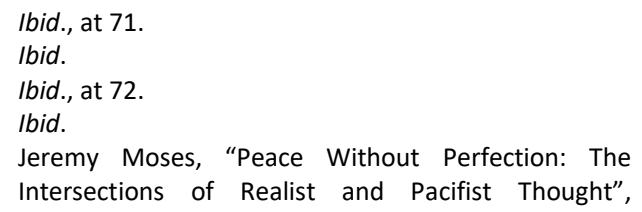

drugs problem tomorrow." The interest in being seen to be a good international citizen is simply the reputational benefit that a country can win for itself, over time, by being regularly willing to pitch into international tasks for motives that appear to be relatively selfless. ${ }^{110}$

Responsibility to prevent focuses more on identifying and tackling the root cause of the fragility of society. Whether it is misrule, uneven distribution of resources and economic growth, or discrimination, the government should have a mechanism that gives them early warnings and a toolbox to create policies and programs to resolve the root cause.

Lastly, the government's political will is vital in assessing early warnings and implementing the toolbox. States must realize that fulfilling the responsibility to prevent fulfills government officials' political interest towards their electorates. It is also a cost-saving stance, and it is valuable for regional and international relations.

\section{Pacifism's View on Mass Atrocities Prevention}

After elaborating on the elements of responsibility to prevent, this section will discuss a pacifist's view in the implementation of R2P to realize that responsibility to prevent is precious. Jeremy Moses adopted a limited definition of a pacifist ethos as a consistent, politically-engaged opposition to a war that simultaneously recognizes the impossibility of the permanent eradication of war. ${ }^{111}$ Responsibility to prevent lies heavily upon pacifism's perspective since such responsibility intends to eradicate needless war and suffering, yet is open

Cooperation and Conflict, vol 53, issue 1, 2017. pp.119 https://doi.org/10.1080/21624887.2017.1409559. Accessed 22 November 2020. 
to the possibility of mass atrocities based on the existence of the obligation to react as another pillar of R2P.

A similar concept to $\mathrm{R} 2 \mathrm{P}$ is 'weak pacifism' as described by Danilo Zolo. The idea of weak pacifism is, in short, designed to offer a non-violent alternative to existing international legal institutions without giving up on the moderating and mediating role that such institutions might provide. The functions that such institutions might take on include 'peacekeeping activities,' conflict mapping and monitoring, 'preventive diplomacy,' impartial and open 'peacemaking institutions,' and weapons control, all of which sound remarkably familiar to the prevention and peacekeeping mechanisms currently available in the United Nations or under the banner of R2P. ${ }^{112}$ Zolo argued that it is necessary to think of ways to 'integrate war' into the international institutional order and that this primarily 'entails the need to activate aggression-controlling mechanisms to reduce the frequency with which conflict between human groups produces destructive effects. ${ }^{113}$

Joe Volk and Scott Stedjan further argued that "western governments have invested hundreds of billions of dollars in the capability to fight and win wars, but little money or time in developing the skills, knowledge, and practical tools necessary to prevent deadly conflict."114 To some extent, their opinion is valid since the debate surrounding R2P focuses more on the intervention element due to the sinister history of the use of the intervention.

112 Jeremy Moses, "Anarchy, Pacifism and Realism: Building a Path to a Non-Violent International Law". Critical Studies on Security, vol.6, issue 2, 2017. Taylor \& Francis Online. pp. 1 - 16, at 10 - 11. https://doi.org/10.1080/21624887.2017.1409559. Accessed on 21 November 2020.

113 Ibid., at 10.

114 Volk, Joe \& Scott Stedjan. "Building Structures for Peace - A Quaker Lobby Offers Strategies for Peacemakers". Responsibility to Protect the Global
Unfortunately, the ability to respond effectively is not constant along the entire evolution of a conflict. As violence increases, the number of actions that are available to peacebuilders decreases. Thus, the tools available to respond to conflict situations or mass human rights abuse decrease as the conflict evolution curve reaches its peak. ${ }^{115}$

Specifically, Jeremy Moses stated that the emphasis on prevention also found a place in the 2005 World Summit Outcomes Document, where the four crimes of genocide, war crimes, ethnic cleansing, and crimes against humanity are connected to R2P, along with the statement that responsibility entails the prevention of such crimes, including their incitement, through appropriate and necessary means. ${ }^{116}$ According to Luck, the focus on prevention in paragraph 139 in A/Res/60/1 "assisting States under stress before crisis break out" - is one of the reasons why the text of the summit outcome document was able to garner anonymous endorsement and emphasis on R2P's non-coercive means was seen by many as a wise strategy for enhancing its political legitimacy. Therefore, prevention has commanded greater political support from States than reactive intervention precisely because prevention is both possible and more conducive to international peace and security than post-conflict reaction. ${ }^{117}$

Hence, it is essential to note that A/Res/60/1's intended spirit is a responsibility to prevent. To gain more

Moral Compact for the 21st Century, edited by Richard H. Cooper \& Juliette Voïnov Kohler, Palgrave MacMillan, 2009, at 205.

115 Ibid., at 203.

116 Moses, Jeremy. "A Pacifist Ethos for the Responsibility to Protect: Detaching Prevention from Intervention". International Politics, vol. 56, no. 2, 2019. pp.228 242, at 233. http://doi.org/10.1057/s41311-017-01385. Accessed on 22 November 2020.

117 Ibid. 
of each other's trust and optimize the practice of R2P, States should fulfill their responsibility to prevent mass atrocities at the national level, rather than continuously improving conflictresponse capability since once the conflict escalates, fewer alternatives will be available for the conflict management. Thus, the conflictresponse ability may not be as useful as a conflict-prevention mechanism.

Similarly to the suggestions given by Volk and Stedjan, ${ }^{118}$ the pacifist implementation to the responsibility to prevent is to: (i) conduct moratorium to the States' budget and funding to support non-governmental organizations, civil society organization, and law enforcement in reducing the fragility of the society; (ii) tighten the regulation on information distribution to avoid misinformation or hate speech; (iii) actively support non-governmental organizations or state's institution in monitoring and identifying the fragility of the society; (iv) adopt policies to deal with horizontal and vertical discrimination; (v) tighten firearms control, both purchase, and distribution; and (vi) reform policies to promote economic growth.

\section{CONCLUSION}

As discussed above, the formation of R2P may be considered a Grotian moment - a paradigm-shifting development in which new rules and doctrines of custom regarding state sovereignty and human rights protection emerge with unusual rapidity and acceptance. R2P bridges the recognition of State's sovereignty and the concern of the international community on human rights protection by bestowing States the primary responsibility to protect human rights and allowing the international community in assisting the States or, if necessary, intervene, in an appropriate manner, based on the Security Council's mandate.

Based on the ILC draft's standard, R2P may be considered a custom since it fulfills the element of state practice and opinio juris. As a Grotian moment, the examination of R2P as a custom does not need all States' practice since its status as Grotian moment 'compensates' R2P from the traditional burden of state practice and opinio juris. Instead, it should focus on the impact of the formation of R2P on international law discourse. Thus, in the analysis, it is provided practice by several States. Additionally, based on the ILC draft, attention should be addressed to the practice of the Security Council's permanent members. Since the permanent members are "particularly involved in the relevant activity or are most likely to be concerned with the alleged rule" or "have an interest at stake" due to the power of the Security Council in giving a mandate for the international community to intervene in the scope of R2P.

In the final analysis, It is demonstrated that the importance of one of the pillars of R2P, responsibility to prevent. In fulfilling such responsibility, States may prevent avoidable, unnecessary conflict. Additionally, it saves States from the trouble of responding to ongoing disputes and rebuilding the affected population. Preventing conflict is also arguably cheaper and has more alternatives than responding to an ongoing conflict. Lastly, by fulfilling the responsibility to prevent, governments gain more trust from the electorates, the neighboring States, and the international community. These reasons should be an incentive for States to fulfill their responsibility to prevent.

Further, the responsibility to prevent and $R 2 P$, in general, should be implemented based on a pacifist perspective that opposes wars but still recognizes the impossibility of the permanent eradication of war. Pacifism perspective fits the concept of R2P since

118 Joe Volk \& Scott Stedjan, supra note 118, at 208 - 209. 
$R 2 P$, in the adoption of $A / \operatorname{Res} / 60 / 1$, was initially intended to focus on prevention mechanisms. Thus, by identifying and tackling the root cause of conflicts in society - such as poverty, misrule, and discrimination - and creating an aggressioncontrolling mechanism to prevent conflict, States may avoid civilians' unnecessary suffering.

\section{REFERENCES}

\section{Book}

Annan, Kofi. We the Peoples, United Nations Department of Public Information, 2000.

ICISS. The Responsibility to Protect: The Responsibility to Protect Report of the International Commission on Intervention and State Sovereignty, The International Development Research Centre, 2001.

Lefkowitz, David. "The Source of International Law: Some Philosophical Reflections". The Philosophy of International Law, edited by Samantha Besson \& John Tasioulas, Oxford University Press, 2010, pp.187- 203.

Mendelson, Maurice H. "The Formation of Customary International Law". Collected Courses of the Hague Academy of International Law, volume 272. Koninklijke Brill NV, 1998.

http://dx.doi.org/10.1163/18758096 pplrdc_A9789041112378_02, pp.155 - 244.

Simma, Bruno \& Philip Alston. "The Sources of Human Rights Law: Custom, Jus Cogens, and General Principles". Australian Yearbook of International Law, vol.12, edited by Philip Alston, et.al, Australian National University, 1989, pp.82- 108.

Volk, Joe \& Scott Stedjan. "Building Structures for Peace - A Quaker Lobby Offers Strategies for Peacemakers". Responsibility to Protect the Global Moral Compact for the 21st Century, edited by Richard H. Cooper \& Juliette Voïnov Kohler, Palgrave MacMillan, 2009, pp.199 218.

\section{Journal}

Alexander, Klinton W. "NATO'S intervention in Kosovo: the legal case for violating Yugoslavia's national sovereignty in the absence of Security Council approval". Houston Journal of International Law, volume 22, number 3, 2000. pp.403 - 449. Gale OneFile: LegalTrac link.gale.com/apps/doc/A62923792/ LT?u=crepuq_mcgill\&sid=LT\&xid=d1 4 ef956.

Baker, Roozbeh B. "Customary International Law in the 21st Century: Old Challenges and New Debates". European Journal of International Law, volume 21, Issue 1, 2010. pp.173 - 204. Oxford Academic. https://doi.org/10.1093/ejil/chq015.

Bellamy, Alex J. \& Paul D. Williams. "The new politics of protection? Côte d'Ivoire, Libya and the responsibility to protect". International Affairs, volume 87 , issue 4,2011 . pp.825 850.

https://ciaotest.cc.columbia.edu/jou rnals/riia/v87i4/f_0022933_18802.p df.

Bellamy, Alex J. "The Responsibility to Protect: Five Years On". Ethics \& International Affairs, vol.24, issue 2, 2010. pp.143 - 169. Wiley Online Library.

https://onlinelibrary.wiley.com/doi/f ull/10.1111/j.17477093.2010.00254.x.

Dagi, Dogachan. "The Russian Stand on the Responsibility to Protect: Does Strategic Culture Matter?". Journal of Asian Security and International Affairs, vol.7, issue 3, 2020. pp.370 386. SAGE Journals. https://journals.sagepub.com/doi/ful l/10.1177/2347797020962667. 
Gegout, Catherine \& Shogo Suzuki. "China, Responsibility to Protect, and the Case of Syria - From Sovereignty Protection to Pragmatism". Global Governance, vol.26, 2020. pp.379 402.

Brill. https://doi.org/10.1163/1942672002603002.

Helfer, Laurence R. \& Ingrid B. Wuerth. "Customary International Law: An Instrument Choice Perspective". Michigan Journal of International Law, vol.37, 2016. pp.563-609. MJIL: Michigan Journal of International Law.

https://repository.law.umich.edu/mji I/vol37/iss4/1/.

Henry, Etienne. "Alleged Acquiescence of the International Community to Revisionist Claims of International Customary Law (With Special Reference to the Jus Contra Bellum Regime)". Melbourne Journal of International Law, vol. 18, issue 2, 2017. pp.1 - 38. SSRN. https://papers.ssrn.com/sol3/papers .cfm?abstract_id=3097867\#.

Iancu, Andreea. "The Responsibility to Protect: A Just War Theory Based Analysis". SEA: Practical Application of Science, vol.2, 2014. pp.341 - 348. https://seaopenresearch.eu/Journals /articles/SPAS_5_47.pdf.

Moses, Jeremy. "A Pacifist Ethos for the Responsibility to Protect: Detaching Prevention from Intervention". International Politics, vol.56, issue 2, 2019. pp.228 - 242. http://doi.org/10.1057/s41311-0170138-5.

"Anarchy, Pacifism and Realism: Building a Path to a NonViolent International Law". Critical Studies on Security, vol.6, issue 2, 2017. pp.1 - 16. Taylor \& Francis Online.

https://doi.org/10.1080/21624887.2 017.1409559.

"Peace Without

Perfection: The Intersections of
Realist and Pacifist Thought". Cooperation and Conflict, vol 53, issue 1, $2017 . \quad$ pp.1 - 19. https://doi.org/10.1080/21624887.2 017.1409559.

Payandeh, Mehrdad. "With Great Power Comes Great Responsibility? The Concept of the Responsibility To Protect Within the Process of International Lawmaking". Yale Journal of International Law, vol.35, 2010. pp.470 - 516. Yale Journal of International Law. https://digitalcommons.law.yale.edu /yjil/vol35/iss2/5/.

Pease, Kelly Kate \& David P. Forsythe. "Human Rights, Humanitarian Intervention, and World Politics". Human Rights Quarterly, vol. 15, Issue 2, 1993. pp.290 - 314. Gale OneFile: LegalTrac.

link.gale.com/apps/doc/A13917979/ LT?u=crepuq_mcgill\&sid=LT\&xid=d7 Ocaf5e.

Posner, Eric A. \& Jack L. Goldsmith. "A Theory of Customary International Law". University of Chicago Law Review, vol. 66, issue 4, 1999. pp.1113 - 1178. https://chicagounbound.uchicago.ed $\mathrm{u} / \mathrm{cgi} /$ viewcontent.cgi?article $=2767$ \& context=journal_articles.

Prost, Mario. "Hierarchy and the Sources of International Law: A Critique". Houston Journal of International Law, vol. 39, issue 2, 2017. pp.285 - 330. Gale OneFile: LegalTrac. link.gale.com/apps/doc/A513193936 /LT?u=crepuq_mcgill\&sid=LT\&xid=88 812092.

Robbins, Melissa. "Powerful States, Customary Law and the Erosion of Human Rights Through Regional Enforcement". California Western International Law Journal, vol. 35, issue 2, 2005. pp.275-302. California Western School of Law. https://scholarlycommons.law.cwsl.e du/cwilj/vol35/iss2/5/. 
Establishing the Status of Responsibility to Protect (R2P) as Customary International Law and Its Role in Preventing Mass Atrocities

Scharf, Michael P. "Accelerated Formation of Customary International Law". ILSA Journal of International and Comparative Law, vol.20, issue 2, 2014. pp.305 - 342. SSRN. https://papers.ssrn.com/sol3/papers .cfm?abstract_id=2479410. . "Seizing the Grotian

Moment: Accelerated Formation of Customary International Law in Times of Fundamental Change". Cornell International Law Journal, vol.43, 2010. pp.439 - 469. SSRN. https://papers.ssrn.com/sol3/papers .cfm?abstract_id=1588283.

Sterio, Milena. "A Grotian Moment: Changes in the Legal Theory of Statehood". Denver Journal of International Law \& Policy, vol.39, issue 2, 2011. pp.209 - 238. Gale OneFile: LegalTrac. link.gale.com/apps/doc/A253224328 $/$ LT?u=crepuq_mcgill\&sid=LT\&xid=48 ff7acc.

Tunkin, Grigory. "Is General International Law Customary Law Only?". European Journal of International Law, vol.4, 1993. pp.534 - 541. http://www.ejil.org/pdfs/4/1/1216.p df.

Weiss, Thomas G., et.al. "The Responsibility to Protect: Is Anyone Interested in Humanitarian Intervention?". Third World Quarterly, vol.25, issue 5, 2004. pp.977 - 992. https://doi.org/10.1080/0143659042 000232063.

Yotova, Rumiana. "Challenges in the Identification of the "General Principles of Law Recognized by Civilized Nations": The Approach of the International Court". Canadian Journal of Comparative and Contemporary Law, vol.3, issue 1, 2017. pp.269 - 323. SSRN. https://papers.ssrn.com/sol3/papers .cfm?abstract_id=3020190.

\section{Other Documents}

European External Action Service. Shared Vision, Common Action: A Stronger Europe, Global Strategy for the European Union's Foreign and Security Policy. Brussel: European External Action Service, 2016.

Foreign Affairs Committee. "Global Britain: The Responsibility to Protect and Humanitarian Intervention: Government response to the Committee's Twelfth Report". 19 November 2018, https://publications.parliament.uk/p a/cm201719/cmselect/cmfaff/1719/ 171902.htm.

Foreign Affairs Department of France. "France Humanitarian Strategy". https://www.diplomatie.gouv.fr/IMG /pdf/Strategie_Humanitaire_ANGlais _2012_cle89af5f-1.pdf.

Global Centre for the Responsibility to Protect. "Reinforcing the Responsibility to Protect in the Central African Republic". http://www.globalr2p.org/media/file s/2015-march-car-brief.pdf.

Hodali, Augustin. "The Implementation of the Responsibility to Protect Norms by the African Standby Force in SubSaharan African". A thesis presented to the Faculty of the U.S. Army Command and General Staff College in partial fulfillment of the requirements for the degree master of military art and science. University of Amsterdam, 2017.

Human Rights Watch. "Syria Events of 2017".

www.hrw.org/worldreport/2018/cou ntry-chapters/Syria.

Ministry of Foreign Affairs of Turkey. "Address by Mr. Ahmet Davutoğlu, Minister of Foreign Affairs of Turkey at the 67th United Nations General Assembly, 28 September 2012, New York". Republic of Turkey, Ministry of Foreign Affairs, http://www.mfa.gov.tr/address-bymr_-ahmet-davutoglu_-minister-of- 
foreign-affairs-of-turkey-at-the-67thunited-nations-general-assembly_28-september.en.mfa.

Norwegian Permanent Mission to the United States in New York. "GA: The Responsibility to Protect". Norwegian Permanent Mission to the United States in New York, https://www.norway.no/en/missions /UN/statements/general-assemblyplenary/2019/ga-the-responsibilityto-protect/.

Ralph, Jason. "Mainstreaming the Responsibility to Protect in UK Strategy - Improving the Government's Response to the Threat of Mass Atrocity". https://una.org.uk/sites/default/files /UNA-

UK\%20Policy\%20briefing\%202\%20-\% 20Professor\%20Jason\%20Ralph\%20\%20Mainstreaming\%20R2P\%20in\%2 0UK\%20strategy.pdf.

Sekulic, Aleksandar. "Responsibility to Protect and Its Effect on Humanitarian Intervention: Libya, Cote d'Ivore, and Syria". A thesis presented for the degree MA in human rights Central European University. Central European University, 2013.

Steenbrink, Laura. "Responsibility to Protect At Stake: R2P in Relation to the US, NATO, and the EU: The Case of Syria". A thesis presented for the degree MA International Relations in Historical Perspective Utrecht University. Utrecht University, 2017.

Turkey's Permanent Mission to the United Nations. "Address by Mr. Fazlı Çorman Charge D'Affaires a.i. and Deputy Representative of Turkey to the UN, "Responsibility to Project" UN General Assembly, 63rd Session". Turkey's Permanent Mission to the United Nations, 24 July 2009, http://turkuissue dt.mfa.gov.tr/Mission/ShowSpeech/ 1183.
United Nations. "Secretary-General Reflects on 'Intervention' in Thirty-Fifth Annual Ditchley Foundation Lecture". United Nations, 26 June 1998, https://www.un.org/press/en/1998/ 19980626.sgsm6613.html.

United States of America Mission in Geneva. "The U.S. Strongly Supports the Concept of Responsibility to Protect (R2P)". United States of America Mission in Geneva, https://geneva.usmission.gov/2012/ 06/19/the-u-s-strong-supporter-ofthe-concept-of-responsibility-toprotect-r $2 p /$.

United States of America Mission to the United Nations. "Remarks at a UN General Assembly Debate on Responsibility to Protect". United States Mission to the United Nations, https://usun.usmission.gov/remarksat-a-un-general-assembly-debate-onresponsibility-to-protect/.

\section{Legal Documents}

Bureau of Conflict and Stabilization Operations. "2020 Report to Congress Pursuant to Section 5 of the Elie Wiesel Genocide and Atrocities Prevention Act of 2018". U.S. Department of State, 7 August 2020, https://www.state.gov/2020-Reportto-Congress-Pursuant-to-Section-5of-the-Elie-Wiesel-Genocide-andAtrocities-Prevention-Act-of-2018.

Case Concerning Military and Paramilitary Activities in and against Nicaragua (Nicaragua v. United States of America), [1986]. I.C.J. Reports of Judgments: Advisory Opinions and Orders of 27 June 1986.

Case Concerning the Temple of Preah Vihear (Cambodia v. Thailand), [1962]. I.C.J. Reports Of Judgments, Advisory Opinions and Orders of 15 June 1962.

Department for International Development, Foreign and Commonwealth Office \& Ministry of Defence. "UK Government Strategy on the Protection of Civilians in Armed Conflict". 
Establishing the Status of Responsibility to Protect (R2P) as Customary International Law and Its Role in Preventing Mass Atrocities

https://assets.publishing.service.gov. uk/government/uploads/system/upl oads/attachment_data/file/32950/u kstrategy-protect-cvilians-armsconflict.pdf.

Department of Foreign Affairs and Trade of Australia. "Department of Foreign Affairs and Trade Annual Report 2018-19". Australian Government, Department of Foreign Affairs and Trade,

https://www.dfat.gov.au/aboutus/publications/corporate/annualreports/Pages/department-offoreign-affairs-and-trade-annualreport-2018-19.

Elie Wiesel Genocide and Atrocities Prevention Act of 2018, 115th Congress of the United States of America Public Law 441.

International Criminal Tribunal for Former Yugoslavia. "Final Report to the Prosecutor by the Committee Established to Review the NATO Bombing Campaign Against the Federal Republic of Yugoslavia". International Criminal Tribunal for Former Yugoslavia, https://www.icty.org/en/press/finalreport-prosecutor-committeeestablished-review-nato-bombingcampaign-against-federal.

International Day of Commemoration and Dignity of the Victims of the Crime of Genocide and of the Prevention of This Crime, GA Res. UN Doc. A/Res/69/323 (2015).

International Law Commission. "Draft Conclusions on Identification of Customary International Law With Commentaries".

https://legal.un.org/ilc/texts/instrum ents/english/commentaries/1_13_20 18.pdf.

Ministry of Defence of France. "French White Paper on Defence and National Security".

https://www.defense.gouv.fr/conten t/download/215253/2394121/White \%20paper\%20on\%20defense\%20\%2 02013.pdf. Accessed 22 November 2020.

North Sea Continental Shelf Cases (Germany/Denmark/Netherlands), [1969]. .IC.J. Report of Judgments of 20 February 1969.

Norwegian Ministry of Foreign Affairs. “Opportunities for All: Human Rights in Norway's Foreign Policy and Development Cooperation". https://www.regjeringen.no/content assets/261f255d028b42cab91ad099 ee3f99fc/en-

gb/pdfs/stm201420150010000engpd fs.pdf.

Resolution 1894 (2009), SC Res UN Doc. S/Res/1894 (2009).

Resolution 1970 (2011), SC Res UN Doc. S/Res/1970 (2011).

Resolution 1973 (2011), SC Res UN Doc. S/Res/1973 (2011).

Resolution 1975 (2011), SC Res UN Doc. S/Res/1975 (2011).

Resolution 2031 (2011), SC Res UN Doc. S/Res/2031 (2011).

Resolution 2085 (2012), SC Res UN Doc. S/Res/2085 (2012).

Resolution 2093 (2013), SC Res UN Doc. S/Res/2093 (2013).

Resolution 2117 (2013), SC Res UN Doc. S/Res/2117 (2013).

Resolution 2134 (2014), SC Res UN Doc. S/Res/2134 (2014).

Resolution 2150 (2014), SC Res UN Doc. S/Res/2150 (2014).

Resolution 2155 (2014), SC Res UN Doc. S/Res/2155 (2014).

Resolution 2196 (2015), SC Res UN Doc. S/Res/2196 (2015).

Resolution 2211 (2015), SC Res UN Doc. S/Res/2211 (2015).

Resolution 2217 (2015), SC Res UN Doc. S/Res/2217 (2015).

Resolution 2419 (2018), SC Res UN Doc. S/Res/2419 (2018).

Resolution Adopted by the General Assembly on 14 September 2009, GA Res. UN Doc. A/Res/63/308 (2009).

Resolution Adopted by the General Assembly: 2005 World Summit 
Outcome, GA Res. UN Doc A/Res/60/1 (2005).

Senate Standing Committee on Foreign Affairs, Defence and Trade of Australia. "Australia's Involvement in Peacekeeping Operations". Parliament of Australia, 26 August 2008,

https://www.aph.gov.au/Parliament ary_Business/Committees/Senate/Fo reign_Affairs_Defence_and_Trade/C ompleted_inquiries/2008-

10/peacekeeping/report/index.

The Case of the S.S. Lotus (France v. Turkey), [1927]. P.C.I.J.: Judgment No.9 of 7 September 1927.

United States of America. "National Security Strategy".

https://obamawhitehouse.archives.g ov/sites/default/files/docs/2015_nat ional_security_strategy_2.pdf. 